\title{
Annual Body Weight Change and Prognosis in Chronic Obstructive Pulmonary Disease [Corrigendum]
}

\author{
Abe Y, Suzuki M, Shima H, et al. Int J Chron Obstruct Pulmon Dis. 2021;16:3243-3253.
}

The authors have advised there is an error with the ethics approval number of Kyoto University on pages 3245 and 3252.

On page 3245, Kyoto University Cohort section, last sentence, the text "(E182 and R03112)" should read "(E182, R03112, and R1660-1)".

On page 3252, Ethics Approval and Informed Consent section, the text "(E182 and R0311-2)" should read "(E182, R0311-2, and R1660-1)".

The authors apologize for these errors.

\section{Publish your work in this journal}

The International Journal of COPD is an international, peer-reviewed journal of therapeutics and pharmacology focusing on concise rapid reporting of clinical studies and reviews in COPD. Special focus is given to the pathophysiological processes underlying the disease, intervention programs, patient focused education, and self management protocols. This journal is indexed on PubMed Central, MedLine and CAS. The manuscript management system is completely online and includes a very quick and fair peer-review system, which is all easy to use. Visit http://www. dovepress.com/testimonials.php to read real quotes from published authors. 